\title{
INVESTIGATION OF GIS BASED MOBILE ROUTE PLANNING - NAVIGATION APPLICATIONS FOR TOURISM ACTIVITIES
}

\author{
Yusuf Kenan Karaş ${ }^{1}$, Lütfi Atay ${ }^{2}$, Hacer Kübra Sevinç ${ }^{3}$, Anday Duru ${ }^{4}$ \\ ${ }^{1}$ Aksaray University, Dept. of Tourism Guidance, Faculty of Tourism, Aksaray, Turkey, yusufkenankaras@aksaray.edu.tr \\ ${ }^{2}$ Çanakkale Onsekiz Mart University, Dept. of Travel Management and Tourism Guidance, Faculty Of Tourism, Çanakkale, Turkey, \\ lutfiatay@comu.edu.tr \\ ${ }^{3}$ Sinop University, Dept. of Computer Technologies, Ayanc1k Vocational School, Sinop, Turkey, kkose@ sinop.edu.tr \\ ${ }^{4}$ Karabuk University, Dept. of Biomedical Engineering, Faculty of Engineering, Karabuk, Turkey, andayduru@ karabuk.edu.tr
}

KEY WORDS: Tourism, Tour, Route, Geographic Information Systems, Route Planning, Navigation

\begin{abstract}
:
Mobile devices can be used in many areas such as shopping, entertainment and education. The number of mobile applications which provides information about a city or region, helps to find route by navigation and makes accommodation plans with food and beverage suggestions, is also increasing. Since these devices are portable and have access to internet, they emerges as a new and important potential for tourism sector. In particular, the increase in the use of route planning and navigation applications, which are location based services within the scope of Geographic Information Systems, has also affected the tourism sector. Which route planning and navigation applications are used extensively by tour operators, tourist guides and individual visitors? What are the strengths and weaknesses about these applications? Answers to such questions were sought in this study.
\end{abstract}

\section{INTRODUCTION}

In recent years, the increase in the use of smart devices can easily be observed and the expansion of their usage areas directly affects many aspects of human life. Individuals of all ages can easily access and use these affordable devices for touristic activities. The increasing use of the applications has been mentioned in many studies as a situation that may threaten the disappearance of the tourist guiding profession in the coming years (Eser et al., 2019; Gökdemir and Göç, 2021). It enables individuals who want to engage in touristic activities to carry out their trips with less expenditure instead of hiring a guide. Instant and free access to information about destinations, routes, accommodation, restaurants and current exchange rates has become more attractive especially for people who are engaged in touristic activities alone (Ercan and Önal, 2007). Another outstanding feature is that accommodation and transportation reservations can be made easily and quickly via smart devices. In addition, tourists actively use these devices not only for access to information, but also for information sharing. The sharing of photo-video shots and travel writings on the visited destinations on various social media platforms reveals the increase in touristic motivation and the intention to participate in tourism activities in those who see these posts. Route finding technology through smart devices used in tourism activities is the most used feature (Kenteris et al., 2009; İşçen and Işık, 2020; Sehng and Shun, 2016).

GIS is an information system that brings spatial and non-spatial data together, performs the processes of collecting, storing, processing, querying, analyzing and presenting to the user in an integrated manner (Yomralıoğlu, 2000).

Location Based Services (LBS) are mobile applications that provide various query functions based on the device location obtained via GPS (GNSS) (Selvi \& Bildirici, 2021).
The most common location-based services are undoubtedly mobile applications that provide route planning and navigation services. These applications, which are also heavily preferred by tour operators, tourist guides and individual visitors, are used extensively in touristic route planning. Some applications can be listed as follows: Waze, Google Maps, MAPS.ME, HERE WeGo, Yandex Maps, MapQuest, Polaris GPS Navigation, Driving and Road Trips, Roadtrippers, Spotted by Locals, HoodMaps.

According to the study of İşçen and Iş1k (2020), it was revealed that the tourist guides working in Turkey mostly use navigation applications on their smart devices. In these applications, Google Maps took the first place and Yandex.Maps took the second place. Apart from this, it has been revealed in the research that the guides use their smart devices a lot, such as accommodation, calculating the exchange rate, and translating. At the same time, Yang and Hsu (2016), according to their study, stated that the most popular navigation application used in the field of tourism is Google Maps.

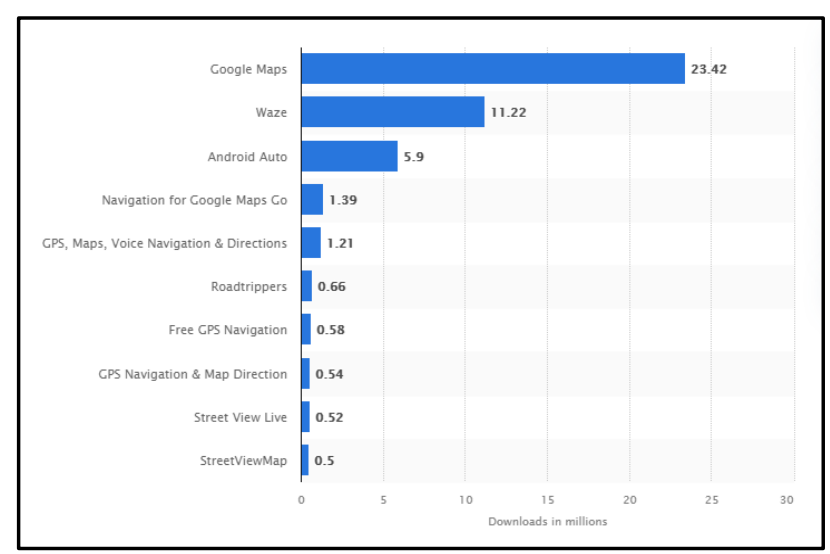

Figure 1: Leading map apps in the United States in 2020 by downloads in millions (Statista, 2021). 
In 2020, Google Maps was the most downloaded map and navigation app in the United States, despite being a standard preinstalled app on Android smartphones. Waze followed, with 11.22 million downloads in the examined period (Statista, 2021). There are no official statistics on maps and navigation in Turkey. Looking at the graph in Figure 1, the most used applications in America are Google Maps, Waze and Android Auto. Android Auto is not available in Turkey. However, when the Google Play Store is examined on the basis of Turkey, one of the most downloaded applications is the Yandex Maps application. In the App Store, Google Maps, Moovit and Yandex Navigation are at the top of the list in Turkey.

In this study, three of these free applications for Route Planning and Navigation were examined. The features, strengths and weaknesses of the applications were evaluated and compared.

\section{GIS BASED MOBILE ROUTE PLANNING- NAVIGATION APPLICATIONS}

\subsection{Waze}

Waze is one of the world's largest GPS/GNSS based route planning and navigation application (Figure 2). It is one of the important mobile applications that can be used effectively for tour operators and tourist guides, especially in crowded cities and long routes, in terms of reliable reporting of instantaneous traffic and road condition changes (Gizikis et al., 2018).

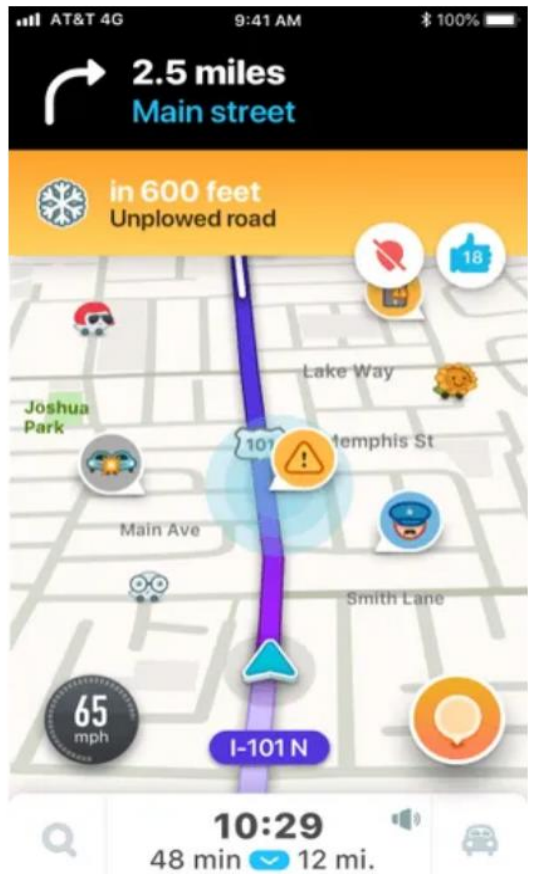

Figure 2: Waze, instant information sharing about the route.

Waze's data source is users and acquires data with feedbacks. It is a navigation application powered by the participation of volunteer users (known as wazers). In this respect, it can be said that it is a social network-based crowdsourcing application.

The data is obtained instantly from the people using the application and the same data is presented to the people using the application. Waze provides navigation based on real-time traffic and road information generated by data from users. Therefore, as road conditions change, redirection is made automatically, the user is warned based on his current speed and road constraints (Figure 3), and the user is informed about the route and destination in advance (Waze, n.d.) (ShiftDelete, n.d.).

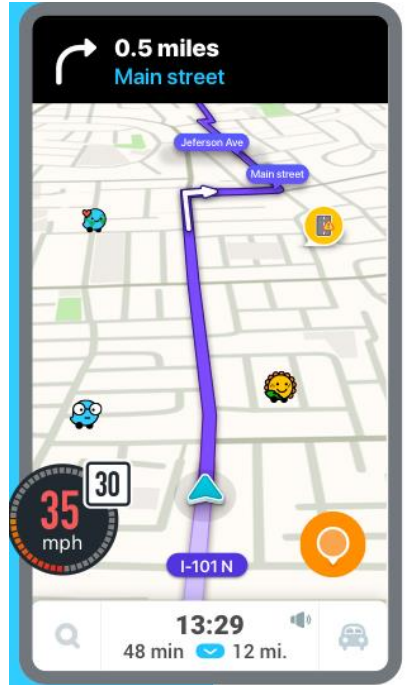

Figure 3. Speedometer helps you stay within the speed limit.

Active data entered by the community to warn other drivers by marking them on the map are: Accidents on the route, traffic density, speed restrictions, traffic signs, roadworks, fuel prices, vehicles abandoned by the roadside, information about local places and businesses, (depending on legal permission in the countries). traffic police, radar and cameras.

Users can warn other drivers by marking the emergence or end of all these information on the map during travel. According to the community, the speed of traffic, congestion on the route and alternative routes are continuously presented to users in real time (Figure 4) (Waze, n.d.) (Waze App, n.d.)
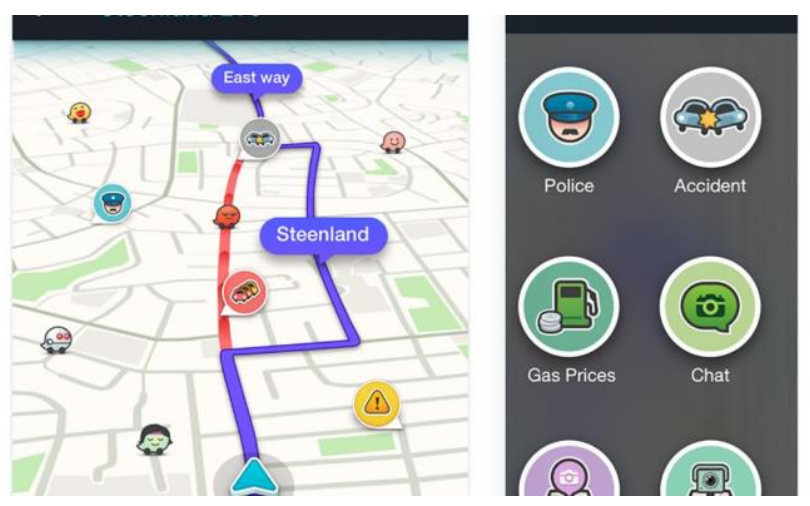

Figure 4. Presentation of alternative route suggestions and notification (active data entry) screen depending on the traffic density in the Waze application.

Apart from these, users also passively feed the system as long as they use the application with instant location information obtained via GPS/GNSS. Speed of traffic flow and traffic density are continuous data transmitted passively. In addition, users also contribute to the establishment of routes that are not yet on the map, thanks to the "Road Paving" feature. 
Users, called Wazer, can earn points as data is added or by scoring the added data. In addition to data entry while driving, users can voluntarily contribute to translation and map editing. Waze won the best general app award at Mobile World Congress in 2013.

In addition to all these advantages, it is seen that Waze has some disadvantages when compared to other navigation applications. Some of these are stated as follows:

- Navigation is not possible by uploading offline maps.

- Since road networks are obtained not from professionally produced map data, but from route data from users, incomplete or incorrect routes can be presented to users. This is especially the case in countries/regions where there are not enough users and feedback, and therefore the application is less used.

- As a requirement of being a crowdsource-based application, the application continuously generates and transmits location information in the background as long as it is running. This causes the GPS/GNSS receiver to be constantly active and the system resources of the device to be consumed quickly.

\subsection{Google Maps}

Google Maps (Google Maps) is a free online mapping service launched by Google. Google Maps also provides API (application programming interface) support for other sites to take advantage of the service. Google Maps; (Figure 5) is a worldwide interactive online and offline mapping service that includes landmarks, road lines, landforms, vector and satellite maps, topographical maps, comments, embedded applications, routing services (Yang \& Hsu, 2016). The application has been the sixth most downloaded application of all time (Ateş \& Sunar, 2019). Google Maps is by far the most widely used Location Based Service provider with satellite images, aerial photographs, street view consisting of panoramic interactive photos, real-time traffic density tracking, detailed route planning navigation application covering most of the world and being integrated into other applications. On the other hand, in areas with low population and access, coverage may be limited in national parks and similar private areas (Manitchalermchai et al., 2020).
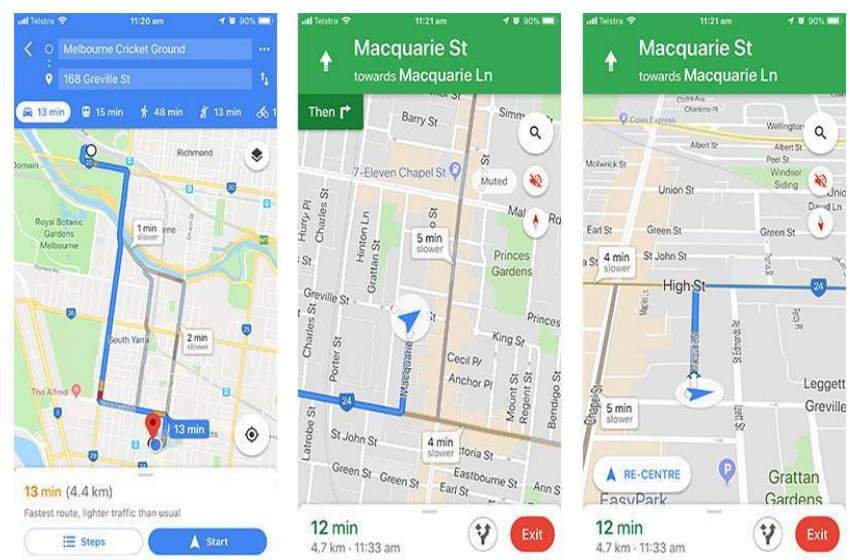

Figure 5. Routing and navigation with Google maps.

On Google Maps, Route Planning can be done with user preference such as private car, public transportation, on foot, by bicycle, and navigation service can be obtained accordingly. It is possible to choose between alternative routes, and routes that include highways, toll roads and ferry crossings can be left out of preference. Google Maps, which measures the traffic density based on the data from all users, can offer drivers the road condition and alternative routes. In addition, it can provide information about the parking situation at the target point depending on the density and how much time should be allocated for parking. In some regions, the Google Maps application can also provide routing services for the needs of disabled users. If the route option "suitable for wheelchair access" is selected in the public transportation option, roads suitable for disabled users can be offered.

With the Street View (Figure 6) feature of Google Maps, streets around the world can be visualized as Panoramic Interactive Photos and the streets can be accessed as if they were alive. Google obtains panoramic photos in many different ways according to the characteristics of the place (Figure 7-8).

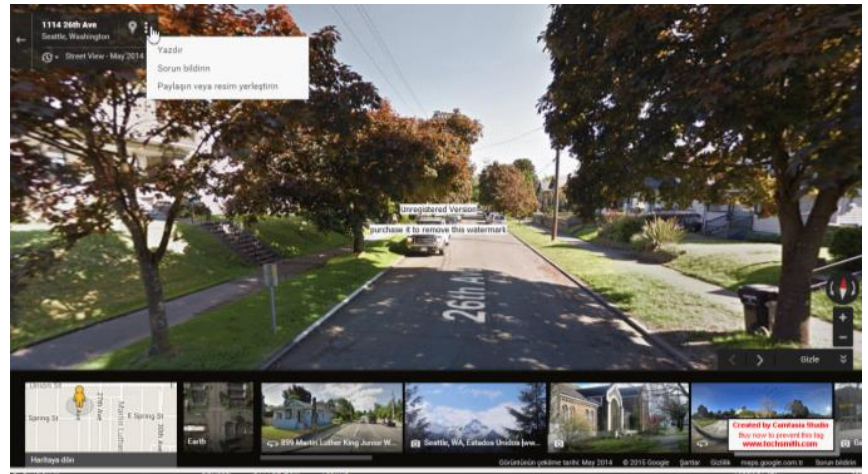

Figure 6. Google maps street view.

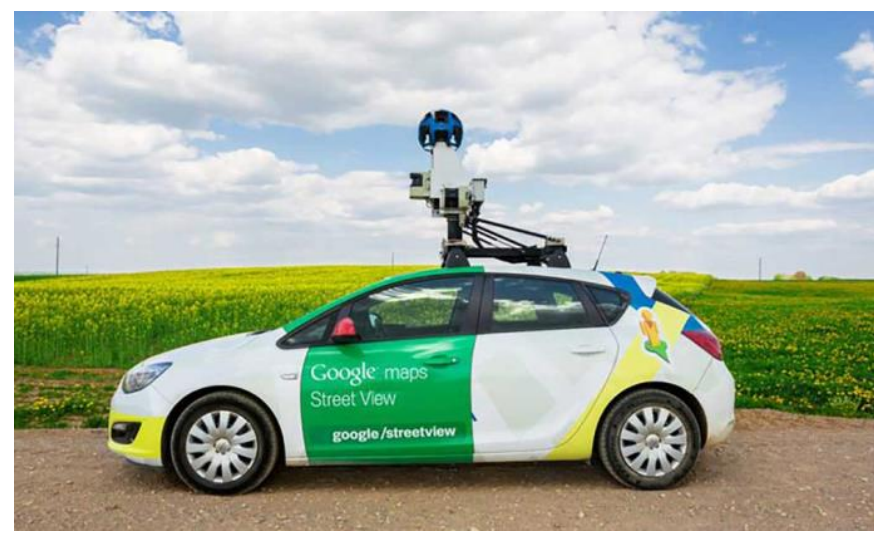

Figure 7. Google car provides panoramic view data.

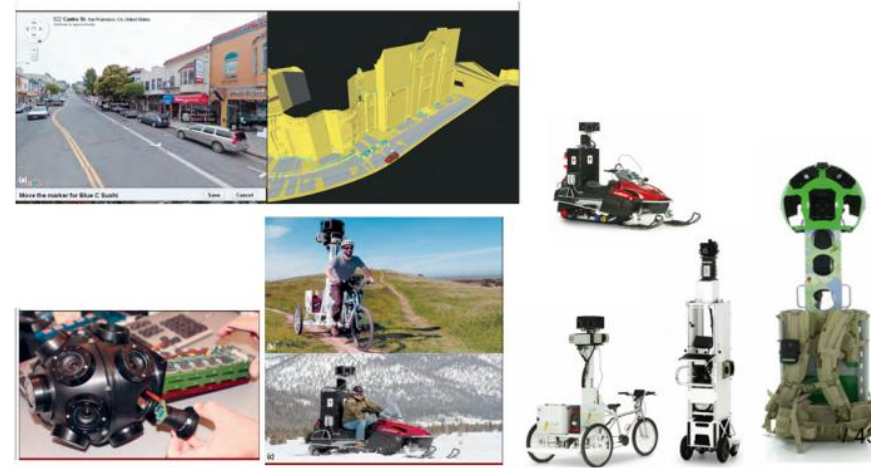

Figure 8. Google street view and panoramic image acquisition methods. 
Google Maps also provides the opportunity to query the cafes, restaurants, historical places, parks, museums and similar popular places next to a certain point according to various parameters (Figure 9a). At the same time, users' ratings and comments about these places can also be seen.

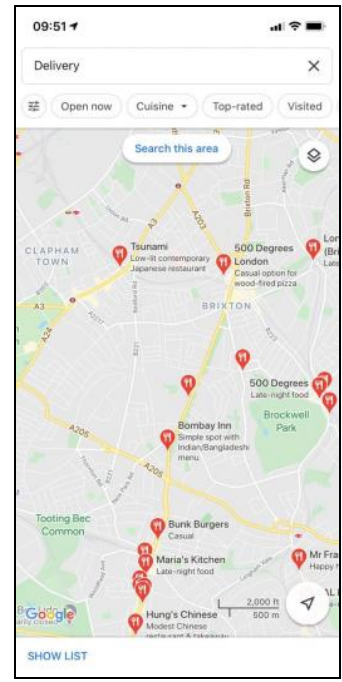

(a)

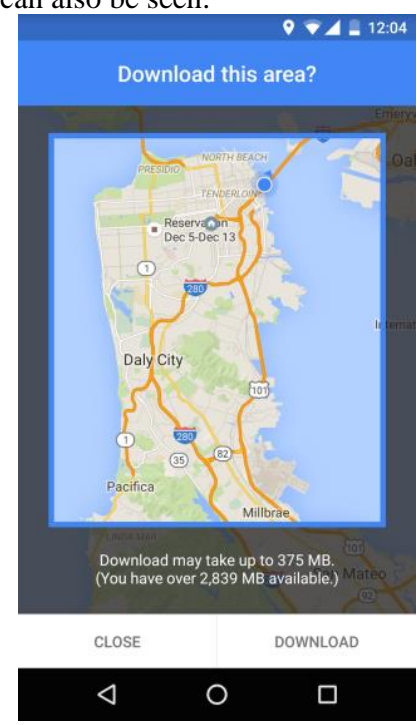

(b)
Figure 9. (a) Querying takeaway restaurants on Google Maps (b) Downloading offline maps on Google Maps

Although the application is mainly used with an internet connection, it also has an offline feature (Figure 9b). This feature is very useful when there is a slow or no internet connection, for example, when traveling abroad. With offline access, the map of the targeted point can be downloaded and used on the application without being connected (Vargonen, n.d.).

\subsection{Yandex Maps}

Yandex navigation and Yandex.Maps are free applications offered by Yandex. Although Yandex.Maps started its service in 2004, Yandex.Navigation became available in Turkey after 2011. (Yandex, n.d.)

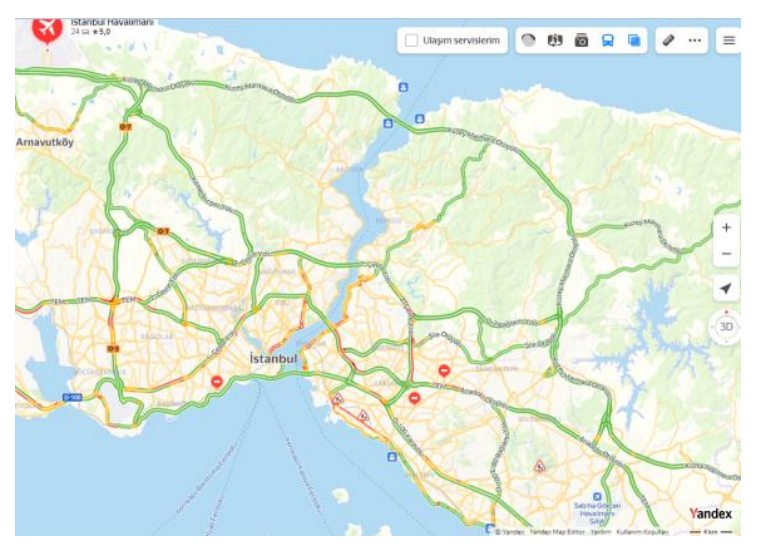

$$
\begin{aligned}
& \text { - traffic is moving freely } \\
& \text { - Traffic is moving slower in this area. } \\
& \text { - Traffic is congested. } \\
& - \text { road blocked }
\end{aligned}
$$

Figure 10. Yandex Maps Istanbul traffic density map and the traffic level is indicated by color.
Yandex Navigation is an application that allows creating routes, searching for addresses and institutions, finding parking spaces, tracking route statistics. Yandex Navigation is specially designed for car users. Yandex Maps is a universal app for the city with car navigation. All the basic features of navigation are also available in Yandex.Maps.

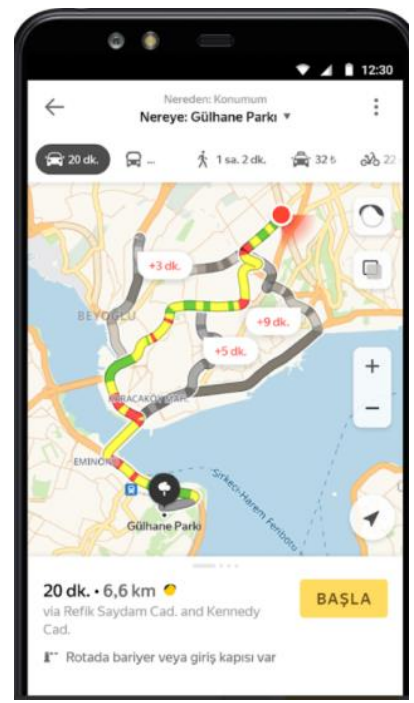

Figure 11. Alternative route suggestion based on traffic density in Yandex Maps

The following information can be obtained with Yandex Maps.

- Detailed maps of more than two thousand cities in Russia and its surrounding countries (due to being a Russia-based application) and countries in Europe (even without internet connection), as well as satellite images from all over the World

- Panorama and floor diagrams of some buildings

- Real-time traffic of public transport vehicles,

- Routes and stops,

- Traffic map showing the current traffic situation in the city (Figure 10)

- New route suggestions according to Traffic Density (Figure 11)

- Information on location, fares and availability, as well as parking spaces, traffic incidents (users can relay information about a traffic incident and participate in "conversations" (Figure 12),

Weather and events, where to eat, where to go with kids, etc.

available as recommendations.

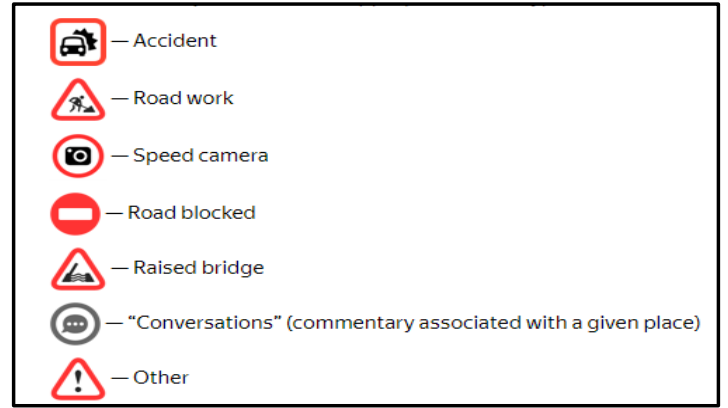

Figure 12. Road warning icons related to traffic events that can be added by users. 
With Yandex Maps, vehicle routes can be created in offline mode without an internet connection. But for offline mode it is necessary to download the necessary maps in advance. (It works the same way in Google Maps.) In addition, routes such as public transportation vehicles such as buses and metro, pedestrian routes, bicycle routes, special bicycle routes can be created.

Edits added by users, such as photos, adding new institutions or businesses to the map, are published after moderation.

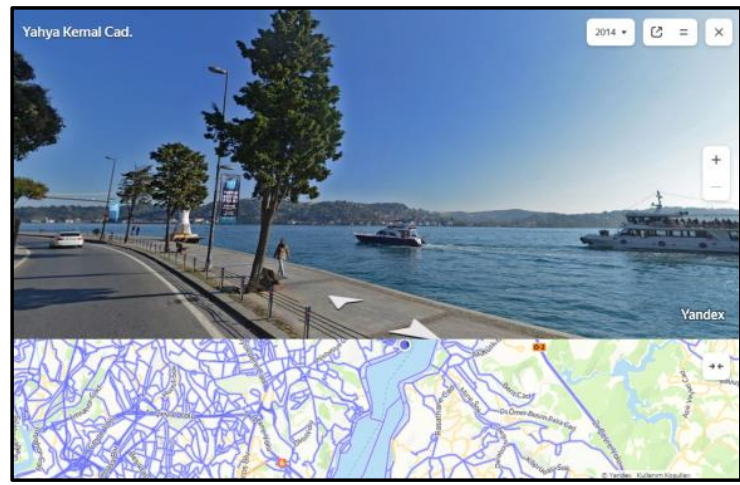

Figure 13. Yandex Maps panoramas (street views) - Istanbul.

In places where it is not possible to pass by car, cameras were placed on bicycles or carried by hand to collect Yandex Maps panorama images (Figure 13). For example, while the shots of the Grand Bazaar in Istanbul were taken from a bicycle, the images in the courtyard of the Blue Mosque in Istanbul, Miniatürk Park and Ankara TCDD Museum were taken with cameras on a tripod (Figure 14), and the images of the Bosphorus were taken from the ferry. (Yandex, n.d.)

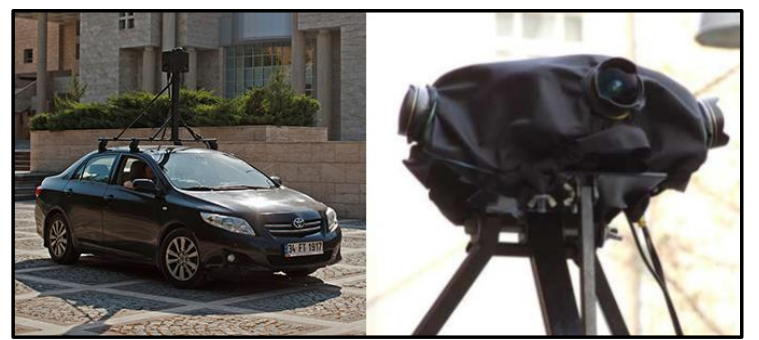

Figure 14. Devices used by Yandex Maps for panorama images.

When analyzed for Turkey, Yandex Maps is an adequate application (Vehicle routing, public transport route creation (Figure 15), bicycle route creation (Figure 16) panorama, etc.) for big cities, but it does not have sufficient information other than vehicle routing for other cities. However, it is sufficient for big cities and contains data suitable for user satisfaction.

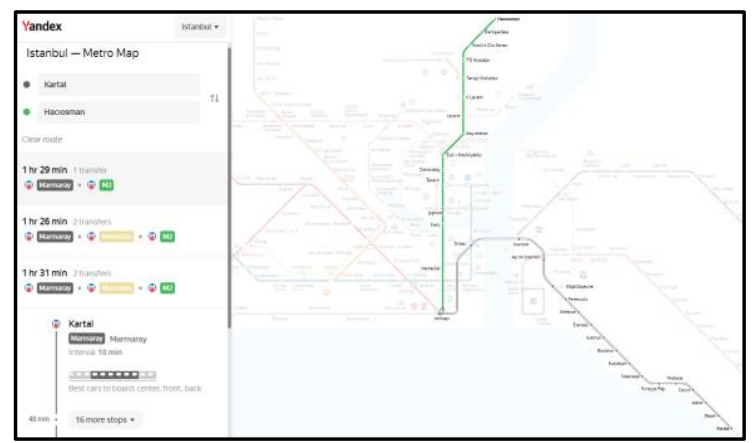

Figure 15. Yandex Maps Istanbul - Metro map

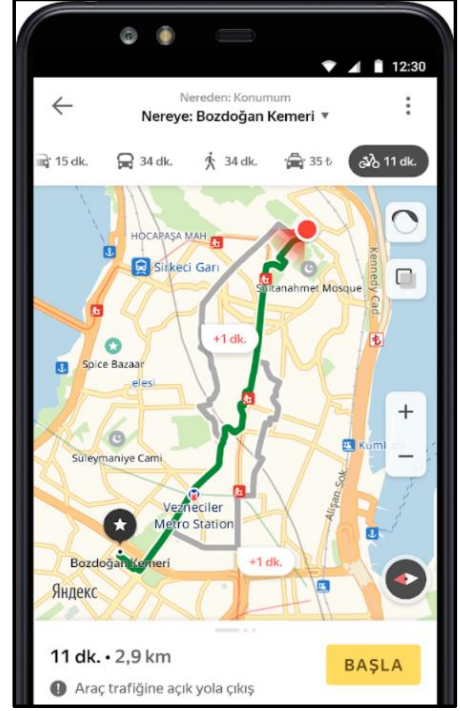

Figure 16. Creating a bike route with Yandex Maps.

\section{COMPARISON OF EXAMINED APPLICATIONS}

The applications examined in this study are classified in Table 1 according to their features and strengths and weaknesses.

\begin{tabular}{|c|c|c|c|}
\hline & Waze & $\begin{array}{l}\text { Google } \\
\text { Maps }\end{array}$ & $\begin{array}{l}\text { Yandex } \\
\text { Maps }\end{array}$ \\
\hline $\begin{array}{l}\text { Providing detailed } \\
\text { information for the city } \\
\text { and tourist attractions }\end{array}$ & No & Yes & Yes \\
\hline $\begin{array}{l}\text { Touristic area } \\
\text { suggestions }\end{array}$ & No & Yes & Yes \\
\hline Reviewing visited places & No & Yes & Yes \\
\hline Rating visited places & Yes & Yes & Yes \\
\hline $\begin{array}{l}\text { Adding visited places to } \\
\text { favorites }\end{array}$ & Yes & Yes & Yes \\
\hline Routing with offline data & No & Yes & Yes \\
\hline Location Sharing & Yes & Yes & Yes \\
\hline $\begin{array}{l}\text { Usage of system } \\
\text { resources }\end{array}$ & High & Low & Low \\
\hline $\begin{array}{l}\text { Crowdsource data } \\
\text { generation }\end{array}$ & Yes & No & Partially \\
\hline Routing accuracy & $\begin{array}{l}\text { Low if } \\
\text { there is } \\
\text { not } \\
\text { enough } \\
\text { users }\end{array}$ & High & High \\
\hline $\begin{array}{l}\text { Traffic density } \\
\text { notification }\end{array}$ & Yes & Yes & Yes \\
\hline $\begin{array}{l}\text { Instant status notification } \\
\text { on the road (Accident, } \\
\text { radar etc.) }\end{array}$ & $\begin{array}{l}\text { Too } \\
\text { high if } \\
\text { there is } \\
\text { enough } \\
\text { users }\end{array}$ & Limited & $\begin{array}{l}\text { Too high } \\
\text { if there is } \\
\text { enough } \\
\text { users }\end{array}$ \\
\hline $\begin{array}{l}\text { Instant alternative route } \\
\text { suggestions }\end{array}$ & Yes & Yes & Yes \\
\hline $\begin{array}{l}\text { Routing for disabled } \\
\text { person }\end{array}$ & No & Yes & No \\
\hline Panoramic Street View & No & Yes & Yes \\
\hline
\end{tabular}

Table 1. Comparison of route planning and navigation based mobile device applications. 


\section{CONCLUSIONS}

In recent years, it is noteworthy that mobile applications are increasingly used in the tourism sector; These practices, which replace traditional methods with their effects such as personalization, speed, transparency and increasing competition, seem to affect the sector in many ways.

In this study, some of the applications that are available free of charge for navigation and route planning in the tourism sector are examined. Evaluations were made on the features and strengths and weaknesses of these applications.

It is thought that such comparisons will be effective and beneficial in the usage preferences of tour operators, tourist guides and individual visitors who use these applications. With more detailed analyzes and evaluations for different categories such as accommodation, ticketing, vehicle rental, route planningnavigation, food and beverage evaluation, the impact of mobile applications in the tourism sector will be better understood.

\section{REFERENCES}

Ateş, A., Sunar, H. (2019, 03 8-9). İvriz Kültürel Peyzaj1 Alanının Çevrimiçi Ziyaretçi Yorumları ile Analizi: Google Haritalar Örneği. ”, Ereğli International Science and Academic Congress.

Ercan, E., Önal, A. (2007). Mobil Turist Rehberlerine Karşılaştırmalı Bakış, IX. Akademik Bilişsim Konferansı Bildirileri.

Eser, S., Cakıc1, A. C., Babat, D., Kızılırmak, İ. (2019). Turlarda Teknoloji Kullanımı: Turistler ve Turist Rehberleri Gözüyle Bir Değerlendirme. Balikesir University Journal of Social Sciences Institute.

İşcen, M., Ișı1k, B. (2020). Turist Rehberlerinin Kullandıkları Mobil Uygulamaların Algılanan Fayda ve Kullanım Kolaylığına Yönelik Nicel Bir Araştırma, Journal Of Business in The Digital Age.

Kenteris, M., Gavalas, D., Economou, D. (2009). An innovative mobile electronic tourist guide application, Pers Ubiquit Comput.

Gizikis, A., Fried, A., Rodriguez, E., Kaufmann, M., Maillefaud, D., \& Donnelly, C. (2018). Exploring the use of Waze for emergency response - Final Report. European Emergency Number Association.

Gökdemir, S., Göç, A. C. (2021). Türkiye'de Turist Rehberliği Alanında Yapılan Teknoloji Konulu Çalışmaların Bibliyometrik Analiz İle Belirlenmesi, Sivas Interdisipliner Turizm Araştırmaları Dergisi.

Manitchalermchai, T., Chotsawasraksa, R., \& Vittayakorn, S. (2020). Electronic map systems for tourist attractions. 8th International Electrical Engineering Congress (iEECON).

Selvi, H. Z., \& Bildirici, İ. Ö. (2021, Nisan 18-22). Konum Tabanlı Hizmetler Teknolojisi İle Yönlendirme Sistemi Tasarımı. TMMOB Harita ve Kadastro Mühendisleri Odası 13. Türkiye Harita Bilimsel ve Teknik Kurultayı.
ShiftDelete, "Waze Çok Iyi. Ama...", https://shiftdelete.net/waze-cok-iyi-ama-46648, (20, December, 2020).

Statista. Leading mapping apps in the United States in 2020, by downloads.

Statista.

https://www.statista.com/statistics/865413/most-popular-usmapping-apps-ranked-by-audience/ (30, Jul 2021).

Vargonen., Google Maps Nedir? Vargonen Blog, https://www.vargonen.com/blog/google-maps-nedir/ (21, December, 2020)

Waze, Waze application Apple Store web page, https://apps.apple.com/tr/app/waze-gps-ve-canl\%C4\%B1trafik/id323229106, (22, December, 2020).

Waze, Waze Web Site. www.waze.com, (20, December, 2020).

Yandex. (n.d.). History of Yandex. Yandex, https://yandex.com/company/history/2004 (15, September, 2021).

Yandex. (n.d.). Panoramic Street Images on Yandex.Maps. https://yandex.com/company/technologies/panoramas/, September, 2021).

Yang, S. Y., \& Hsu, C. L. (2016). A location-based services and Google maps-based information master system for tour guiding. Computers \& Electrical Engineering.

Yomralığlu, T. (2000). Coğrafi Bilgi Sistemleri, Temel Kavramlar ve Uygulamalar. 